\begin{tabular}{l} 
POLITEIA POLTEIA: Jurnal Ilmu Politik \\
Politeia: Jurnal Ilmu Politik, 11 (1) (2019): 1-9 \\
ISSN 0216-9290 (Print), ISSN 2549-175X (Online) \\
Available online https://jurnal.usu.ac.id/index.php/politeia \\
\hline
\end{tabular}

\title{
Islamic Activism, Local Politics, and Contradiction of Democratisation in North Sumatra
}

\author{
Faisal Riza* \& Junaidi \\ Department of Islamic Political Thought, Faculty of Ushuluddin and Islamic Studies \\ State Islamic University of North Sumatra
}

Received in December 2018, Approved in December 2018, Published January 2019

\begin{abstract}
Abstrak
Makalah ini berfokus pada meneliti tentang transformasi aktivisme Islam di Sumatera Utara terutama gerakan mereka, yang didengungkan oleh Aksi Bela Islam di Jakarta 2016, di wilayah ini pasca-hukuman Basuki Tjahaja Purnama di tahun antara 2017 dan 2018. Studi ini menganalisis gerakan mereka dalam menjaga narasi politik, wacana Islam yang diintimidasi, dan kemudian semua ini telah dikapitalisasi untuk kepentingan politik dalam pemilihan daerah seperti pemilihan gubernur di Sumatera Utara 2018. Studi ini didekati dengan teori gerakan sosial, gerakan sosial Islam, dan kemudian menjadi terkait dengan proyek demokratisasi dan narasi kontemporer nasionalisme Indonesia. Studi ini berpendapat bahwa pertama, gerakan ini masih bergerak lebih lama daripada yang diprediksi banyak sarjana karena kemampuan mereka untuk menjaga wacana dan menganalisis peluang struktur politik. Kedua, fragmentasi dalam tubuh gerakan tidak dapat dihindari karena disorientasi kerja dan hubungannya dengan elit politik dan politik elektoral. Ketiga, bayang-bayang keberadaan gerakan ini tetap menjadi tantangan besar bagi proyek demokratisasi di Sumatera Utara dan umumnya Indonesia.
\end{abstract}

Kata Kunci: Gerakan Sosial, Elit Politik, Demokratisasi.

\begin{abstract}
This paper focus on examining the transformation of Islamic activism in North Sumatra especially their movement, which was echoed by the Aksi Bela Islam in Jakarta 2016, in this region in post- punishment of Basuki Tjahaja Purnama between 2017 and 2018. The study analyses their movement in keeping the narration of politics, discourse of intimidated Islam, and then all these have been capitalised for political interest in regional election such as governor election in North Sumatra 2018. The study is approached by social movement theory, Islamic social movement, and then being related to the project of democratization and the contemporary narration of Indonesia nationalism. This study argues that firstly, this movement is still going on move longer than many scholar predicted because their ability to keep discourse and analize political structure opportunity. Secondly, fragmentation in the body of movement can not be avoided because working disorientation and their relation with political elit and electoral politics. Third, the shadow of this movement existence remains a big challenge for democratization project in North Sumatra and generally Indonesia.
\end{abstract}

Keywords: Social Movement, Political Elites, Democratization

How to cite: Riza, F. \& Junaidi. (2018), Islamic Activism, Local Politics, and Contradiction of Democratisation in North Sumatra, Politeia: Jurnal Ilmu Politik, Vol 11, (1): 1-9

\footnotetext{
${ }^{*}$ Corresponding author:

E-mail: faisalriza@uinsu.ac.id
} 


\section{INTRODUCTION}

The 2016 Islamic Defendant Action Movement (Aksi Bela Islam) in Jakarta demanding punishment for Basuki Tjahaja Purnama (Ahok) for blaspheming the Koran is a phenomenal movement. Although similar movements are not new in Indonesia and especially in Muslim-majority countries in the world, this movement has a unique side such as Peace Action and echoes to various parts of Indonesia. Many observers consider that the Islamic solidarity movement, which is voluminous Islamic Defensive Action, does not last long, one of the reasons being the assumption that the movement is a short-term political movement, namely the 2016 Jakarta Election, furthermore, this movement will end when the Ahok verdict demands applying inclusion. Although in some areas confirmation can be obtained of this assumption, but this situation is different from what happened in North Sumatra. This movement is gaining momentum for several reasons. First, since the beginning of the Islamic solidarity movement at the end of 2016, North Sumatra was in fact an area that made a big noise. Secondly, a similar situation had been experienced by Muslims in Medan when the Medan regional election in 2010. At that time, one of the figures competing in the Pilkada was Sofyan Tan, this figure got resistance from Islam because he was of ethnic Chinese, religious Christian, and supported by PDIP. Third, there are regional head elections at the provincial and district levels which are simultaneously carried out here. Incidentally, the figures who participated in this event were figures identified as people who were attached to the Basuki Tjahaja Purnama (Ahok) figure, Djarot Saiful Hidayat, former deputy governor of DKI Jakarta during Ahok's leadership and returning in pairs in the DKI 2017 Pilgub. Muslim resistance more and more because they assume that Djarot is a figure who is equally troubled when leading Jakarta, then, this situation provides new opportunities for Islamic movements such as North Sumatra GNPF and GAPAI SU to do long work as in the Ahok case in Jakarta.

This study wants to explore how the movements of this movement maintain the discourse they build that is useful for prolonging the life of the movement, maintaining tension and caring for support from Muslim supporters.

\section{Definition and Theory of Social Movements}

To facilitate the operation of a comprehensive discussion and understanding in this chapter we will parse the definition of the Social Movement and the theoretical debate among theorists about developing approaches in this matter, including specifically the theory of Islamic social movements. These theories were also reviewed and discussed, then tested and used in approaching the phenomenon of social movements from the AntiBlasphemy Movement of North Sumatra.

Social movements are understood as a group of people or organizations that are diffusely organized that strive towards common goals related to human society or social change. In addition, social movements are loosely organized 
but sustainable campaigns to support social goals, usually the application or prevention of changes in the structure or value of societies. Although social movements differ in size, all are basically collective in nature, and that is, they come together spontaneously but the relationship is not defined by rules and procedures but only sharing common views in society.

All definitions of social movements reflect the idea that social movements are intrinsically related to social change. They do not cover the activities of people as members of stable social groups with established structures and norms and values that are undoubted. Member behavior of social movements does not reflect the assumption that the social order will continue as it is. This reflects, conversely, the belief that people collectively can bring or prevent social change if they will dedicate themselves to pursuing goals. Non-committed observers may regard these goals as illusions, but for their members is a hope that is quite capable of being realized. Social movements are not everyday movements, habits, but behaviors that are influenced by the purpose of the movement that is to bring changes in the way things "always" have been done or sometimes prevent changes.

Some of the main theories of social movements have been put forward for years and how these theories can explain the birth and growth and or dissolution of certain social movements. Here also we can see how some of these theories run in dealing with social movements of the internet era, such as the controversial anti-globalization movement. In the theory of deprivation, some social movements are born when certain people or certain groups of people feel that they do not have certain goods, services, or resources (McAdam, McCarthy, \& Zald, 1988). Some Islamic circles, especially those belonging to the ABI movement feel that their rights are not fulfilled by the current regime. The rights they perceive as the right to express the values and teachings of Islam are not accommodated by the present government. However, this movement presupposes the struggle for resources. They consider that Islamic mastery in terms of resources is considered very minimal because the allocation and distribution of resources is more controlled by people who they consider to be agents of liberal capitalism and Chinese communism. The term "resources" in this context refers to things such as money, labor, social status, knowledge, media support and political elites, and so on.

One of the great advantages of this theory is that it offers a convincing explanation of why in some situation some complaints can give birth to successful social movements, whereas in other situations the same type of complaint may not produce anything similar. However, there are social movements that are born even when resources are especially scarce (Starr, 2000), Starr discusses in detail how many "new" social movements are categorized by many under the umbrella term "antiglobalization movement" trying to mobilize resources power, especially human resources, by submitting requests to grassroots organizers. These grassroots organizers first tried to gather workers in their area, then to unite them in mid-level regional meetings, and finally organize protests (and even 
boycotts) at the national and international levels. Now mobilization models for such protests have almost shifted to the presence and extraordinary influence of modern technology (the Internet, cell phones). Petitions, protests and claims are mobilized through websites.

The next theory is the theory of political processes. This concept treats social movements as a type of political movement in which the origins of social movements are traced to the availability of political opportunities. More precisely, this theory sees social movements in question to the state or responsible governmental powers. If the government's position is deeply rooted and also vulnerable to repressive behavior, it is likely that social movements may fail. Conversely, if the government is weak or more tolerant of differences in attitudes, it is likely that every social movement born may have the opportunity to grow and develop (Dobson, 2001). However, the main problem with this political process theory is that this approach emphasizes the importance of political conditions and companion political opportunities in determining opportunities for success for newborn social movements.

In the Islamic movement discourse some literature proposes different terms and may be conceptually close together. The term Islamic movement has been generalized as Islamism. Islamism appears to have a variety of representations and is used to describe the phenomenon of its complexity. For example, the term Islamic fundamentalism which is interpreted as a big paying of many terms including 'Islamic movements',' Islamic politics', 'Islamic activism', 'Islamic revival' or 'revivalism', and 'neopolitical religious movements', and' Islamism ' (Bayat, 2005). The concept of fundamentalism emphasizes the essence of literal interpretation. This pattern emphasizes the traditionalism of the movement. In different versions fundamentalism is a belief in exclusive poses of a unique truth (Gellner, 2013). The alternative term for fundamentalism is neo-political religion or "new religious politics". This term was proposed by Keddie to make it more neutral and clearly distinguish between politics and the weight of the movement (Keddie, 1998). In addition, there is also the term 'Revivalism' or 'resurgence' which emphasizes that religion is loaded with political content in this movement. In the context of the term 'political Islam', this is meant for an Islamic movement that emphasizes their political nature. Islamism is sometimes released by Islamic circles, even though state control over people's lives and almost every practice of Islamic life in their families, schools and other public spaces becomes political.

Finally, the term 'Islamic activism', which is meant to see and take into account the inclusion of various types of activities, political, social and cultural, which appear under the rubric of the Islamic movement (Bayat, 2005). The concept, said Bayat, has no specificity to point to the recent increase in actions in Indonesia. Discourse analysis of texts, words and symbols can explain the methodological orientation that applies to discover the nature of the Islamist movement. And many 'fundamentalist' arguments get their raw 
material from this type of data. They tend to recognize Islam as a religion and Islamism as a political project by ignoring variations over time in the perception of religion, practices and institutions among various segments of the population in certain societies and between different Muslim countries. A dynamic and changing view of movement is often overshadowed by static vision. The Islamist movement is often presented as a very homogeneous and coherent social unit that must be identified by their ideological discourse. There is little interest in dissecting movements to uncover the layers and orientation of their constituents. Many Islamic narratives treat it simply in terms of religious revivalism, expressions of primordial loyalty, or as something unique and unique that conventional social science cannot analyze.

\section{RESEARCH METHODOLOGY}

\section{Type of Research}

This study uses a type of discursive approach. The researcher chose to use this approach because it has been considered more representative of the variety of movement narratives that became a subset in it. It is also considered appropriate in exploring the meaning of people's behavior as a dynamic community, the development of their movements from one moment to another.

\section{Data Collection}

There are several steps that I have taken in collecting data, including; a) Observation: our observation activities were carried out among others by following and seeing several organizational meetings and demonstrations in the field, seeing activities, listening to speeches, and responding to the demonstrators in this process; b) interviews, which we conducted was in-depth interviews with several figures who were members of the GNPF and GAPAI SU. In addition, we also conducted interviews with supporters of this movement. In this work, we talked a number of times when the demonstration took place, another time a light conversation was held at a mosque and coffee shop. In terms of helping to record data and information when observing and interviewing, we use tools here such as voice recorder applications on smartphones, photos and stationery; c) Our document studies are carried out on program reports, leaflets circulating in action, meeting documents, and the like. All of these are very useful to expand and to sharp the analysis of the discourse developed by the GAPAI elites to its supporters.

\section{Data management}

After the data been collected, the next activity is to process the data which is classifying, correlating and filtering it out. The results are then adjusted to the discussion plan and research objectives.

\section{Analysis of data}

Data analysis was carried out with a discursive approach. In this case the theory of discourse analysis is used to look at Islamic political discourse developed in the social movement. Methodologically this step follows the method of Manuel Castells which emphasizes that social movements must be seen by "their own discourse". When presenting and analyzing movements, I will follow very closely their own words, not just ideas, as recorded in the document where I work, because, like Castells, the identity of the movement is spoken by those who speak. The Castell method is useful beyond the structuralist position he has followed by deducing the 
nature of the movement from the location of the actor class, by looking on the contrary to what they actually say they want. However, this kind of discourse analysis has its own drawbacks, raising some difficult questions. Given the fragmented nature of contemporary movements, who speaks for those movements? Is it Ideologists, leaders, various layers of constituents? Most accounts are restricted by relying solely on the language of ideologists. Another problem is how to distinguish what the speaker means by what they say, especially in times of transition and uncertainty when words can have many meanings. In addition, later, the theory of Islamic activism of Asef Bayat was also operated to examine the structure of motion, polarization, and fragmentation that worked in the Islamic movement. Furthermore, we use the political opportunity structure theory approach as one of the established theories of social movements, to see how the movement plays in looking at the political opportunities provided by the structural environment.

\section{Fabrication of Religious Issues}

Why can a movement last longer than expected? How can SU GAP and GNPF maintain the tension of the movement? A social movement theorist Asef Bayat said that a key element of a protest movement was sustainability (Bayat, 2012), meanwhile, Hilman Latief when commenting on the Bela Islam Action movement stressed that the solidarity and protest movements had the potential to transform into a longterm social movement if sustained by strong discourse (Latief, 2017: 213).
In the frenzy of the ABI in 2016, several issues raised by $\mathrm{ABI}$ supporters cover many things. Beyond the issue of blasphemy, other issues with more scope appearing and being the subject of public discussion. Several things was debated include the issue of social justice, economic domination by certain groups, the arrival of thousands of workers from China, the rise of communism and, or rather the PKI, Western domination of the Islamic world, the efforts of others to destroy Islam in Indonesia and so on. The Bayat and Hilman theories can be used as analytical tools to see how effective the GAPAI and GNPF movements are, especially how when they gain momentum. Sentimental political discourse is a major challenge in the project of developing democratization in North Sumatra, and this political trail of hatred is basically not the first to occur in the direct regional head elections here at least after the reformation in Indonesia. Indeed, for regions with a pluralistic society the maintenance of social political harmony is not easy, development that is expected to create a democratic culture released from traditional ties turns out to have its own complexity. "Native Sons", "Native and Non-native Groups", faithful religious rules, and tribalism cannot be absent from the government agenda (Riza, 2011).

The anti-Chinese riots of 1998 illustrate how the peak of racism tensions here, then in 2008 when the North Sumatra governor voted Rudolf Pardede, a Christian served as a successor to Tengku Rizal Nurdin in the last half of the leadership period, wanted to run as Governor of North Sumatra 2008 -2013. Immediately, resistance from Islamic 
circles emerged, the anti-plurality sentiment maneuver appeared in the form of "Coalition of the Ummah", at that time. Furthermore, in 2010 at the Medan City Election event, when Sofyan Tan, one of the figures competing in the regional election event, this figure gained resistance from the Islamic community because he was of ethnic Chinese, Christian, and supported by PDIP (Indonesia Democratic Party-Struggle). As a result, Sofyan Tan lost to these identity factors (Aspinall, Dettman, \& Warburton, 2011). Then, in 2018 there will be a regional head election at the provincial and district levels which is simultaneously carried out here. Incidentally, the figures who participated in this event were figures identified as people who were attached to the Basuki Tjahaja Purnama (Ahok) figure, Djarot Saiful Hidayat, former deputy governor of DKI Jakarta during Ahok's leadership and returning in pairs in the DKI 2017 Pilgub. Muslim resistance more and more because they assume that Djarot is a figure who is equally troubled when leading Jakarta, then, this situation provides new opportunities for Islamic movements such as North Sumatra GNPF and GAPAI SU to do long work as in the Ahok case in Jakarta. They built a narrative on three things at the same time which hampered Djarot's winning work in North Sumatra. First, the issue of the Koran defamation carried out by Ahok in Jakarta 2016, where Djarot was considered involved in it because he was a candidate for Deputy Governor of Basuki Tjahaja Purnama, PDIP as his Djarot party also supported and backed Ahok. Second, Djarot as not the son of the region, Djarot himself came from Blitar, East Java, had been mayor there for two periods, then was assigned by his party to accompany Ahok in Jakarta since 2015. Third, Djarot in his participation as Governor accompanied by Sihar Sitorus, a descendant Toba Bataks and Christians who act as candidates for their Deputies.

In addition to discourse fabrication, there is also discourse amplification through social media such as Facebook, Twitter, WhatsApp, and Youtube. The GAPAI network uses this means of amplification effectively and massively so that mass mobilization in every movement agenda can always be said to be crowded and successful. In short, here can be put forward the argument that this Islamic movement can last long and get support because their ability to produce religious issues and amplify them later in accordance with the mind and inner state of society, this ability also presupposes adaptation to social situations and political momentum, then, fabrication the issue is also supported by strength

\section{Elite Fragmentation Challenges}

The phenomenon of $\mathrm{ABI}$ from the beginning shows the symptoms of plurality and fragmentation of Islamic authorities in Indonesia. Rizik Shihab's is a figure who was proclaimed as a High Priest of Indonesian Muslims attracted many supporters and made it a new authority outside of figures from mainstream organizations such as NU and Muhammadiyah (Burhani, 2016). In addition, internally, as a movement in addition to strengthening work also must be able to maintain the solidity of the organization and management of conflict, when conflict fails to be managed, fragmentation and division cannot be avoided. GAPAI does not escape from fragmented experience, this situation can be seen due to several 
factors, among others; first, the trap of political pragmatism. The sentimental political discourse of this movement did get public support and sympathy because it was seen as a sympathetic and Islamic action. However, if viewed from the typical problem or issue raised by this movement, it can be understood later that similar issues have always become political pragmatism. The large membership of GAPAI SU and GNPF (around 40 Islamic Organizations) basically raises some basic questions, especially about how they manage issues to maintain the tension of the movement, and the stability of the sense of togetherness, how. The polarization and plurality of mass organizations incorporated in this movement certainly cannot be simplified, and what is more be uniformed in terms of interests. The diversity of backgrounds and characteristics of Islamic organizations within GAPAI is a challenge for them in maintaining their cohesiveness, especially after demonstrations of increasingly wild political issues are characterized by mutual claims among elites about who has the most right to bring the aspirations of Muslims. As a solidarity movement, the power of issues is the key to maintaining cohesiveness between different groups to stay in line and transform the energy they have to make the desired changes.

Second, the political pragmatism of this movement is closely related to the internal elite of the organization and the local political elite who have an interest in the regional head election. In Medan, during the solidarity movement of the Islamic Defendant Action in Jakarta 2016, a demonstration of solidarity that has been here since the beginning has been seen in the shadow of several figures which later ran for Governor. In the early days, among the political figures which were present at the demonstration was Tengku Erry Nuradi, at which time he also acted as Governor. His presence in this action could not only be interpreted as a presence as a Governor, but his arrival at this forum opened opportunities for interpretations of political opportunities which he might have achieved especially sympathy from thousands of demonstrators. Many state officials want to come in various actions but not all are accepted by the GNPF and GAPAI SU. One of them is the head of Police of Republic of Indonesia (KAPOLRI) Tito Karnavian. Up to this point, we can see that this movement seems very close to Tengku Erry Nuradi, this strife is increasingly visible when the rejection scenarios emerge from GAPAI and GNPF against candidates recommended by political parties. In short, this scenario is that they affirm themselves as channeling the aspirations of Muslims by the way any candidate for Governor and Deputy Governor who will be recommended by political parties must consult and get recommendations from GAPAI and GNPF.

Then, during the election of the Governor of North Sumatra 2018 entering the registration stage, there was an internal turmoil by GAPAI which responded to the decision of the Gerindra Party along with the PKS, PAN, Nasdem, and Golkar coalitions to support Edy Rahmayadi and Musa Rajekshah in the North Sumatra Pilgub. Gerindra's decision was apparently rejected by the North Sumatra Ulema Fatwa Guard Movement (GNPF). They even urged Gerindra to revoke its support for the 
candidates for Governor and Deputy Governor who had been carried. The rejection of the GNPF was delivered directly by the General Chairperson of North Sumatra's GNPF, Heriansyah, in a letter dated January 6, 2018 which was addressed to the General Chairperson of the Gerindra DPP, Prabowo Subianto. Apart from the reason the candidate who was supported by Gerindra was considered as a figure whose helped degrade the spirit 212, another reason raised by the GNPF for the rejection was because of the joining of the "Religious Defiance Supporting Party" in the coalition. As is known, the religious opponents referred to by GNPF are Basuki Tjahaja Purnama alias Ahok, while the party which is considered the party supporting supporters of religion is the party that carried Ahok in the 2016 Jakarta election, namely Hanura, Nasdem, Golkar, and PDIP. In his letter, the GNPF said that if the Gerindra Party still carries the recommended candidates at this time, then the Party would lose the trust of the North Sumatra Ulama GNPF and Islamic community organizations incorporated in it and the Muslims in general. However, along with the ongoing political dynamics, the political attitude of GAPAI and GNPF is increasingly not directed and very pragmatic. Previously they refused the pair Edi Rahmayadi and Musa Rajekshah but later they accepted.

Another internal maneuver from GAPAI SU and GNPF is the efforts of the leaders to take part in the regional head election. There are those at the provincial level and others at the district level. At the provincial level, Rabualam as the chairman of GAPAI SU declared itself as a candidate for the Governor of North Sumatra 2018-2023. Rabualam desire as a candidate for the Governor had caused polemics in the internal GAPAI and GNPF. He was considered to have done so as something other than the organization's agreement and the ulama's decision at the GNPF, therefore he was considered to claim to be acting on behalf of Muslims for his personal ambitions. Rabualam itself believes that his efforts to declare itself to improve the welfare of Muslims that have not been achieved so far, Muslims have not been completely independent, he said. Heriansyah as chairman of the North Sumatra GNPF MUI nominated himself as deputy regent of the district of Langkat on the 2018 post-conflict local election in the district. Once again, this move of Rabualam and Heriansyah is actually not too surprising. Because their dream of being a leader in the era of regional autonomy has long been embedded, Rabualam had tried twice the regional elections in Deli Serdang in 2008 and 2013, while things that were more or less the same also happened to Heriansyah.

\section{CONCLUSION}

The Islamic movement which seen in the ABI volumes and having supporting organs up to the level of regional regions in Indonesia shows that Islamic solidarity is still a glue togetherness factor. Discourse fabrication, sentimental issues of religion, regionalism, and identity politics have become key factors supporting the survival of this movement more than many observers had expected. However, the movement of this model and the discourse they carry actually gives a sense of concern about the space for democratization that is missing. Forcing public narratives, sentimental, hate-based, and antipluralistic political narratives, of course, seriously jeopardizes the development of 
the democratization project in Indonesia because this project requires the support of a moderate, pluralist and tolerant civil movement.

\section{BIBLIOGRAPHY}

Aspinall, E., Dettman, S., \& Warburton, E. (2011). When religion trumps ethnicity: A regional election case study from Indonesia. South East Asia Research, 19(1), 27-58. https://doi.org/10.5367/sear.2011.003 4

Bayat, A. (2005). Islamism and social movement theory. Third World Quarterly, 26(6), 891-908. https://doi.org/10.1080/01436590500 089240

Burhani, N. (2016). Aksi Bela Islam Konservatisme: Konservatisme dan Fragmentasi Otoritas Keagamaan. Jurnal Maarif, Vol.11, No. 2, 15-29.

Dobson, C. (2001). Social movements: A summary of what works. The Citizen's Handbook: A Guide to Building Community in Vancouver. Retrieved December 2, 2006

Gellner, E. (2013). Postmodernism, reason and religion. Routledge.

Keddie, N. R. (1998). The new religious politics: where, when, and why do "fundamentalisms"

appear?. Comparative studies in society and history, 40(4), 696-723.

Latief, H. (2016). Solidaritas Islam Dan Gerakan Sosial Pasca "Aksi Bela Islam" 2016, Jurnal Maarif, Vol.11, No. 2, 203-217.

McAdam, D., McCarthy, J. D., \& Zald, M. N. (1988). Social movements. In N. J. Smelser (Ed.), Handbook of sociology (pp. 695-737). Thousand Oaks, CA, US: Sage Publications, Inc.

Riza, F. (2011). The Involvement of Ulama in the Medan Mayoral Election of 2010 Faisal Riza. In Workshop on Muslim Religious Authority in Contemporary
Asia. Singapore: Asia Research Institute, NUS.

Starr, A. (2000). Naming the enemy: Anticorporate movements confront globalization. London: Zed Books.

\section{Website}

https://www.britannica.com/topic/soci al-movement, accesed on 16-10-2018

https://sumutpos.co/2016/12/03/gubs u-saya-bilang-ahok-kalian-bilangtangkap/ accessed on 25-09- 2018

https://nasional.tempo.co/read/843220 /gapai-sumatera-utara-menolakkehadiran-kapolri-di-medan accesed on 25-09- 2018

https://www.cnnindonesia.com/pilkad aserentak/nasional/2018031305423 2-32-282484/gnpf-ulama-bantahbuat-perjanjian-dengan-edyrahmayadi? Accessed on 25-09-2018

http://www.medanbisnisdaily.com/ne ws/read/2018/02/26/338695/gnp f-ulama-deklarasikan-dukungeramas/ accessed on 25-09-2018

http://www.medanbisnisdaily.com/ne ws/read/2017/11/22/327426/pem bina-gnpf-mui-sumut-rabualamdeklarasi-cagub/ accessed on 25-092018

http:// www.rmolsumut.com/read/201 8/02/18/54707/PasanganSulistianto-Heriansyah-JalaniSidang-Kedua-Sengketa-PilkadaLangkat-?page=1 accessed on 25-092018

https://www.facebook.com/heriansyah untuklangkat/ accessed on 25-092018

https://www.facebook.com/heriansyah untuklangkat/ accessed on 25-092018 